\title{
PELATIHAN TEKNIK PENULISAN PENELITIAN TINDAKAN KELAS PADA GURU OTOMATISASI DAN TATA KELOLA PERKANTORAN DI KABUPATEN WONOGIRI
}

\author{
Patni Ninghardjanti ${ }^{1}$, C. Dyah Sulistyaningrum Indrawati², \\ Chairul Huda Atma Dirgatama ${ }^{3}$, Arif Wahyu Wirawan ${ }^{4}$ \\ ${ }^{1,2,4}$ Program Studi Pendidikan Administrasi Perkantoran, Universitas Sebelas Maret \\ ${ }^{3}$ Program Studi D3 Manajemen Administrasi, Universitas Sebelas Maret \\ ning@staff.uns.ac.id, ciciliadyah@staff.uns.ac.id, \\ chairul_huda@staff.uns.ac.id, arif_wahyu@fkip.uns.ac.id
}

\begin{abstract}
Abstrak
Guru merupakan pendidik profesional yang memiliki tugas, fungsi, dan peran penting dalam mencerdaskan kehidupan bangsa. Profesi guru perlu ditingkatkan dan dikembangkan secara terus menerus dan proporsional menurut jabatan fungsional guru. Berdasarkan pengamatan dan studi pendahuluan bahwa sebagian besar guru belum dapat membuat penelitian Tindakan kelas untuk menunjang kinerja dan kenaikan pangkat. Hal ini terlihat dari banyaknya guru yang mengalami kesulitan untuk naik jabatan dan kepangkatannya. Penyebab dari permasalahan tersebut, yaitu: 1) Guru kurang memahami tentang konsep Penelitian Tindakan Kelas (PTK), 2) Guru kurang memahami tentang pelaksanaan Penelitian Tindakan Kelas (PTK), dan 3) Guru kurang memahami tentang penyusunan laporan Penelitian Tindakan Kelas. Pelatihan penelitian tindakan kelas bertujuan untuk meningkatkan kinerja guru dalam pembuatan laporan penelitian tindakan kelas dan artikel luaran dari penelitian yang dilakukan menuju guru yang professional. Hasil yang diperoleh dari pelatihan yaitu: 1) Kemampuan guru dalam membuat penelitian tindakan kelas (PTK) telah tercapai sebesar 100\%, 2) Kemampuan guru dalam membuat laporan penelitian tindakan kelas (PTK) telah tercapai sebesar 75\%, serta 3) Peningkatan kinerja guru dalam produktifitas melakukan sebuah penelitian dan membuat karya ilmiah telah tercapai sebesar $80 \%$.
\end{abstract}

Kata Kunci: teknik penulisan, PTK, SMK

\section{PENDAHULUAN}

Berdasarkan Peraturan Menteri Negara Pendayagunaan Aparatur Negara dan Birokrasi Reformasi (PermenPAN) Nomor 16 Tahun 2009 tentang Jabatan Fungsional Guru menjelaskan bahwa syarat kenaikan pangkat bagi seorang guru menjadi golongan III-C ke atas, wajib membuat publikasi ilmiah dan atau karya inovatif. Publikasi ilmiah dapat meliputi hasil penelitian atau gagasan inovatif pada bidang pendidikan formal dan publikasi buku pelajaran, buku pengayaan, dan pedoman guru. Sedangkan untuk karya inovatif meliputi menemukan teknologi tepat guna, menemukan atau menciptakan karya seni, membuat atau memodifikasi alat pelajaran/peraga/praktikum, dan mengikuti pengembangan penyusunan standar, pedoman, soal dan sejenisnya.

Guru merupakan pendidik profesional yang memiliki tugas, fungsi, dan peran penting dalam mencerdaskan kehidupan bangsa (Hunaepi, 2016). Profesi guru perlu ditingkatkan dan dikembangkan secara terus menerus dan proporsional menurut

$$
\text { Pendidikan }
$$


jabatan fungsional guru. Selain itu, tugas dan fungsi yang melekat pada jabatan fungsional guru dilaksanakan sesuai dengan aturan yang berlaku, maka diperlukan penilaian kinerja guru yang menjamin terjadinya proses pembelajaran yang berkualitas di semua jenjang pendidikan.

Pentingnya standar mutu profesional guru untuk menjamin proses belajar mengajar dan hasil belajar yang bermutu. Pengembangan standar kemampuan profesional guru memerlukan pemikiran yang mendasar, sistematik, sistemik, serta upaya yang konsisten dan berkesinambungan (Rahmatullah \& Inanna, 2019). Untuk meyakinkan bahwa setiap guru adalah seorang yang profesional dalam bidangnya, maka penilaian kinerja guru harus dilakukan terhadap guru di semua satuan pendidikan formal yang diselenggarakan oleh pemerintah, pemerintah daerah dan masyarakat. Guru tidak hanya terbatas pada guru yang bekerja di satuan pendidikan di bawah kewenangan Kementerian Pendidikan dan Kebudayaan, tetapi juga mencakup guru yang bekerja di satuan pendidikan di lingkungan Kementerian Agama. Hasil dari penilain guru dan evaluasi diri digunakan untuk menyusun profil kinerja guru sebagai dasar penyusunan program Pengembangan Keprofesian Berkelanjutan.

Hasil pengamatan dan studi pendahuluan di wilayah Kabupaten Wonogiri menunjukkan bahwa sebagian besar guru pada proses pengembangan karier dan kepangkatan masih menghadapi kendala. Hal ini terlihat dari banyaknya guru yang mengalami kesulitan untuk naik jabatan dan kepangkatannya. Penyebab dari permasalahan tersebut terdiri dari beberapa hal, yaitu (1) Guru kurang memahami tentang konsep Penelitian Tindakan Kelas (PTK), (2) Guru kurang memahami tentang pelaksanaan Penelitian Tindakan Kelas (PTK), dan (3) Guru kurang memahami tentang penyusunan laporan Penelitian Tindakan Kelas.

Menurut Kemmis dan Mc. Taggart dalam Pardjono (2007: 9) Penelitian Tindakan merupakan proses berfikir reflektif secara kolektif yang dilaksanakan oleh partisipan didalam situasi sosial tertentu agar dapat meningkatkan rasionalitas dan keadilan dari praktik praktik sosial dan pendidikan dan dapat meningkatkan pemahaman mereka terhadap praktik dan situasi yang berlangsung. Sedangkan menurut Mills dalam Craig A. Mertler (2009: 4) Penelitian Tindakan didefinisikan sebagai penyelidikan sistematis yang dilakukan oleh guru, administrator, konselor, atau orang lain yang memiliki kepentingan dalam proses belajar mengajar atau lingkungan untuk tujuan mengumpulkan informasi tentang bagaimana sekolah mereka beroperasi, bagaimana mereka mengajar, dan bagaimana siswa belajar.

Penelitian Tindakan Kelas (PTK) merupakan karya tulis ilmiah guru untuk perbaikan mutu proses belajar mengajar (Saiful, 2015); (Soejoto, 2017). Menurut Arikunto (2012: 3) "Penelitian Tindakan Kelas (PTK) atau Classroom Action Research adalah penilitian yang dilakukan didalam kelas". Penelitian menunjuk pada suatu kegiatan mencermati suatu objek dengan menggunakan cara dan atau aturan metodologi tertentu untuk memperoleh data atau informasi yang bermanfaat dalam meningkatkan mutu suatu hal yang menarik minat dan penting bagi seorang peneliti. Penelitian Tindakan Kelas merupakan salah satu penelitian yang lebih baik dilakukan oleh seorang guru sebai pelaksana program Kegiatan Belajar Mengajar (KBM) di kelas. PTK juga dapat dikatakan penelitian yang mengkombinasikan prosedur penelitian dengan tindakan subtantif, suatu tindakan yang di lakukan dalam disipin inkuiri, suatu usaha untuk memahami apa yang terjadi dalam sebuah proses perbaikan dan perubahan. Hal ini menunjukkan bahwa sangat penting bagi guru untuk melakukan PTK (Siswani, 2016); (Supriyanto, 2017); (Rustiana, 2019). Berdasarkan observasi dan analisa dilapangan bahwa guru Otomatisasi dan Tata Kelola Perkantoran khususnya di Wilayah Kabupaten Wonogiri masih belum memahami secara detail mengenai Teknik Penulisan Penelitian Tindakan Kelas dan hasil laporan yang dihasilkannya.

Dengan adanya permasalah tersebut, maka diperlukan adanya pelatihan lebih lanjut terkait Teknik Penulisan Penelitian Tindakan Kelas kepada guru MGMP Sekolah Menengah Kejuruan (SMK) bidang Otomatisasi dan Tata Kelola Perkantoran di Wilayah Kabupaten Wonogiri. Hal ini diperlukan untuk menambah motivasi dan meningkatkan kompetensi guru yang tergabung dalam MGMP Otomatisasi dan Tata Kelola Perkantoran di Kabupaten Wonogiri tentang pemahaman dan keterampilan melaksanakan serta membuat laporan Penelitian Tindakan Kelas. 
Tujuan Pelatihan dalam Pengabdian Kepada Masyarakat ini yaitu 1) Meningkatnya kemampuan guru dalam membuat penelitian tindakan kelas (PTK), 2) Meningkatnya kemampuan guru dalam membuat laporan penelitian tindakan kelas (PTK), serta 3) Meningkatnya kinerja guru dalam produktifitas melakukan sebuah penelitian dan membuat karya ilmiah.

\section{METODE}

Pengabdian kepada masyarakat berlangsung pada bulan Juni - Agustus 2020. Khalayak sasaran pelatihan ini yaitu MGMP Otomatisasi dan Tata Kelola Perkantoran di Kabupaten Wonogiri. Metode pelatihannya adalah pelatihan langsung yang dilakukan tim pengabdian kepada masyarakat Grup Riset Teknologi Komunikasi dan Perkantoran Program Studi Pendidikan Administrasi Perkantoran FKIP UNS. Pelatihan dilaksanakan sesuai sintaks atau tahap kegiatan pengabdian yang telah ditentukan saat kerjasama dengan mitra sebagai berikut: 1) Tahap sosialisasi menjelaskan tujuan diadakannya pelatihan, 2) Tahap focus group discussion (FGD) yang bertujuan untuk mengidentifikasi permasalahan yang ada dilapangan dan penyamaan persepsi PTK, 3) Tahap pelatihan Teknik penulisan PTK 4) Tahap monitoring dan evaluasi pelaksanaan, serta 5) Masukan stakeholder dan revisi.

\section{HASIL DAN PEMBAHASAN}

\section{Pelatihan Teknik Penulisan Penelitian Tindakan Kelas}

Pelatihan Teknik Penulisan Penelitian Tindakan Kelas Pada Guru Otomatisasi Dan Tata Kelola Perkantoran dilaksanakan pada tanggal 2128 Agustus 2020 dilakukan selama 34 Jam Pembelajaran. Pada tanggal 21 Agustus 2020 dilakukan secara luring yang bertempat di Aula SMK Negeri 1 Wonogiri, Sedangkan pada tanggal 22-28 Agustus 2020 dilakukan secara daring untuk meminimalisir penyebaran virus covid 19. Kegiatan ini dilaksanakan untuk Musyawarah Guru Mata Pelajaran (MGMP) Otomatisasi dan Tata Kelola Perkantoran (OTKP) di Kapubaten Wonogiri yang diikuti oleh 20 guru. Pelatihan ini diadakan karena sebagian besar guru masih mengalami kesulitan untuk naik jabatan dan pangkat. Penyebab dari permasalahan tersebut terdiri dari beberapa hal, yaitu (1) guru kurang memahami tentang konsep Penelitian Tindakan Kelas (PTK), (2) guru kurang memahami tentang pelaksanaan Penelitian Tindakan Kelas (PTK), dan (3) guru kurang memahami tentang penyusunan laporan Penelitian Tindakan Kelas, sehingga mitra menginginkan diadakannya Pelatihan Teknik Penulisan Penelitian Tindakan Kelas Pada Guru Otomatisasi Dan Tata Kelola Perkantoran.

Materi pelatihan disampaikan oleh tim pengabdian kepada masyarakat Grup Riset Teknologi Komunikasi dan Perkantoran Program Studi Pendidikan Administrasi Perkantoran, Universitas Sebelas Maret Surakarta. Materi yang disampaikan berkaitan dengan Teknik Penulisan Tindakan Kelas dan Implementasinya. Jabaran materinya yaitu: mengenai konsep PTK yang meliputi definisi PTK, tujuan dilaksanakan PTK, manfaat PTK, karakteristik PTK, dan bagaimana cara mengidentifikasi permasalahan yang muncul saat pembelajaran dan beberapa isu yang bisa diangkat dalam PTK. Pelatihan ini memberikan materi yang bersifat mendasar dan lebih ke araf aplikatif. Materi yang disampaikan secara teori tidak terlalu banyak, namun penekanan lebih kepada bagaimana melakukan PTK di sekolah.

Dalam kegiatan pengabdian kepada masyarakat ini, Guru-guru sangat antusias dalam menyampaikan permasalahan-permasalahan yang muncul dan sering dihadapi selama pembelajaran dapat dijadikan Penelitian Tindakan Kelas (PTK). Permasalahan tersebut dicari metode pemecahan masalah, selanjutnya guru diberikan kesempatan untuk menyusun proposal PTK terkait dengan pembelajaran di mata pelajaran yang diampu. Setelah diberikan tugas, Pengabdi bersepakat dengan mitra untuk melakukan tindak lanjut pengabdian melalui kegiatan pendampingan antara tim pengabdi dengan para guru-guru untuk bimbingan proposal yang dibuatnya.

\section{Peningkatan Kinerja Guru melalui Pelatihan Teknik Penulisan Penelitian Tindakan Kelas}

Pelatihan Teknik Penulisan Penelitian Tindakan Kelas Pembelajaran bertujuan untuk meningkatkan kinerja guru dalam pembuatan dan punulisan Penelitian Tindakan Kelas. Peningkatan kinerja guru terdapat pada tabel berikut ini:

$$
\text { Pendidikan }
$$




\begin{tabular}{|l|l|c|c|}
\hline No & \multicolumn{1}{|c|}{ Parameter } & $\begin{array}{c}\text { Sebelum } \\
\text { Pelatihan }\end{array}$ & $\begin{array}{c}\text { Sesudah } \\
\text { Pelatihan }\end{array}$ \\
\hline 1 & $\begin{array}{l}\text { Kemampuan membuat Penelitian Tindakan } \\
\text { Kelas (PTK) }\end{array}$ & $40 \%$ & $100 \%$ \\
\hline 2 & $\begin{array}{l}\text { Kemampuan membuat laporan Penelitian } \\
\text { Tindakan Kelas (PTK) }\end{array}$ & $30 \%$ & $75 \%$ \\
\hline 3 & $\begin{array}{l}\text { Peningkatan Kinerja Guru dalam } \\
\text { produktifitas melakukan sebuah penelitian } \\
\text { dan membuat karya ilmiah }\end{array}$ & $30 \%$ & $80 \%$ \\
\hline
\end{tabular}

Pelatihan Penulisan Tindakan Kelas memiliki tujuan yaitu: 1) Meningkatnya kemampuan guru dalam membuat penelitian tindakan kelas (PTK), 2) Meningkatnya kemampuan guru dalam membuat laporan penelitian tindakan kelas (PTK), serta 3) Meningkatnya kinerja guru dalam produktifitas melakukan sebuah penelitian dan membuat karya ilmiah. Peningkatan kinerja guru terdapat pada gambar berikut ini:

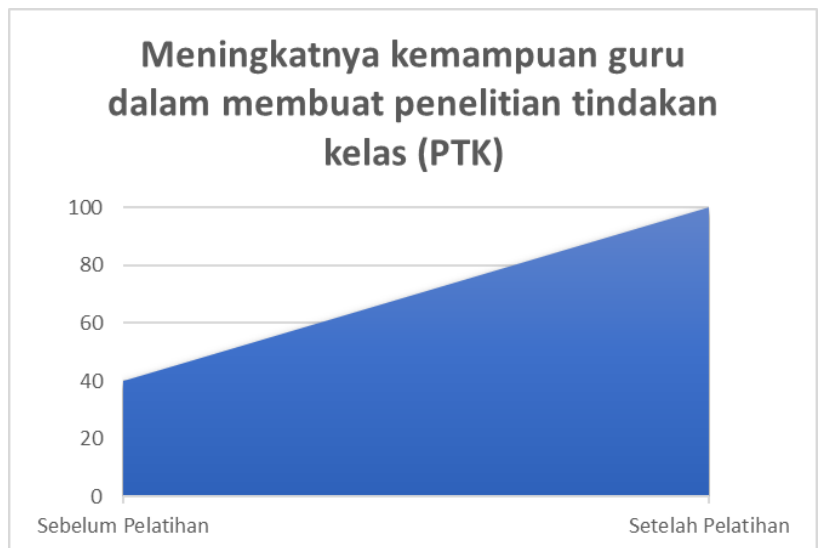

Gambar 1: Kemampuan Guru dalam membuat PTK

Berdasarkan gambar 1 mengenai kemampuan guru dalam membuat PTK terlihat terjadinya peningkatan yang sangat tinggi, pada saat sebelum pelatihan menunjukkan $40 \%$ dan setelah pelatihan meningkat menjadi $100 \%$. Hal tersebut terjadi peningkatan kemampuan guru dalam membuat PTK sebesar 60\%.

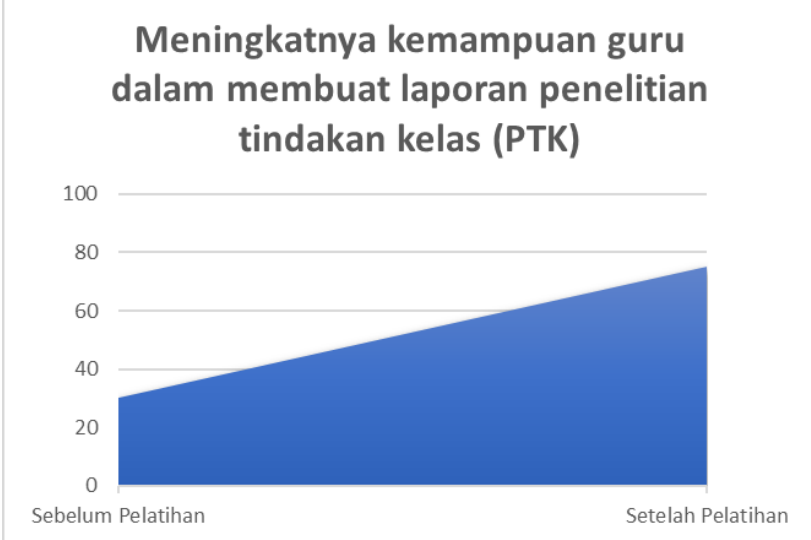

Gambar 2: Kemampuan Guru dalam membuat laporan PTK

Berdasarkan gambar 2 mengenai kemampuan guru dalam membuat laporan PTK terlihat terjadinya peningkatan yang tinggi, pada saat sebelum pelatihan menunjukkan $30 \%$ dan setelah pelatihan meningkat menjadi $75 \%$. Hal tersebut terjadi peningkatan kemampuan guru dalam membuat laporan PTK sebesar $40 \%$.

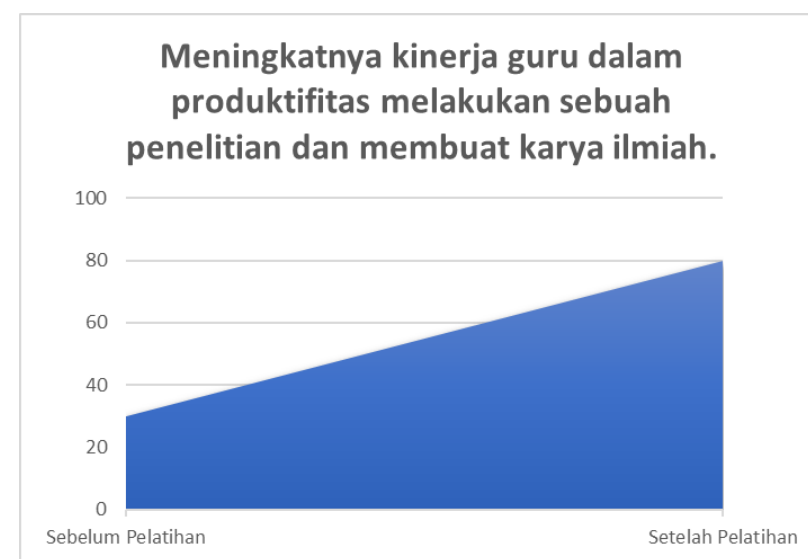

Gambar 3: Kinerja guru dalam produktifitas melakukan sebuah penelitian dan membuat karya ilmiah

Berdasarkan gambar 3 mengenai kinerja guru dalam produktifitas melakukan sebuah penelitian dan membuat karya ilmiahterlihat terjadinya peningkatan yang sangat tinggi, pada saat sebelum pelatihan menunjukkan $30 \%$ dan setelah pelatihan meningkat menjadi $80 \%$. Hal tersebut terjadi peningkatan Kinerja guru dalam produktifitas melakukan sebuah penelitian dan membuat karya ilmiah sebesar 50\%. 


\section{KESIMPULAN}

Kesimpulan yang didapat dalam pengabdian kepada masyarakat ini adalah sebagai berikut:

1. Pada Pelatihan Teknik Penulisan Penelitian Tindakan Kelas (PTK) bertujuan memberi pemahaman mengenai pentingnya hasil luaran atau jurnal bagi guru dalam meningkatkan kompetensi pada seorang Guru.

2. Luaran hasil penelitian atau jurnal seebelumnya harus melakukan sebuah penelitian.

3. Penelitian yang digunakan dalam menyusun sebuah jurnal pada Guru adalah Penelitian Tindakan Kelas.

4. Teknik penulisan Penelitian Tindakan Kelas ini dilakukan guna mengevaluasi proses pembelajaran yang dilakukan oleh Guru, sehingga kompetensi dan hasil yang diharapkan dari Guru dan Peserta Didik dapat mendapatkan hasil maksimal.

5. Tanggapan Guru dengan adanya kegiatan Pelatihan Teknik Penulisan Penelitian Tindakan Kelas ini yaitu sangat membantu guru dalam menulis dan memotivasi Guru untuk selalu melakukan sebuah penelitian guna menghasilkan luaran jurnal yang dapat di publikasikan secara Nasional maupun Internasional.

\section{UCAPAN TERIMAKASIH}

Ucapan terimakasih disampaikan kepada Musyawarah Guru Mata Pelajaran Otomatisasi dan Tata Kelola Perkantoran Kabupaten Wonogiri yang telah bersedia bekerjasama dalam pelaksanaan kegiatan pengabdian kepada masyarakat.

Ucapan terimakasih juga disampaikan kepada LPPM Universitas Sebelas Maret Surakarta yang telah berkontribusi dan mendukung pelaksanaan kegiatan pengabdian kepada masyarakat.

\section{REFERENSI}

Arikunto, Suharsimi. (2012). Prosedur Penelitian Suatu Pendekatan Praktek. Jakarta: Rineka Cipta.

Hunaepi. (2016). Pelatihan Penelitian Tindakan Kelas (PTK) dan Teknik Penulisan Karya Ilmiah Bagi Guru di Mts. Nw Mertaknao. Lumbung Inovasi: Jurnal Pengabdian Kepada Masyarakat, 1(1), 38-40.

Rahmatullah \& Inanna. (2019). Pelatihan Penulisan Penelitian Tindakan Kelas Bagi Guru. Jurnal Dedikasi Masyarakat, 3(1), 19 - 25.

Rustiana, Novi. (2019). Pendampingan merancang penelitian tindakan kelas dan penulisan publikasi kepada guru-guru SD di desa Sakatiga. Jurnal Pemberdayaan: Publikasi Hasil Pengabdian kepada Masyarakat, 3(3), 367-372.

Saiful, P., Hunaepi, Taufik S. (2015). Kajian Kemampuan Guru dalam Melaksanakan PTK dan Menyusun Karya Ilmiah. PKPSM IKIP Mataram: Laporan Penelitian.

Siswani, M, D., Suwarno. (2016). PTK dengan Pembelajaran Berbasis Kearifan Lokal dan Penulisan Artikel Ilmiah di SDN Kalisube Banyumas. Khazanah Pendidikan: Jurnal Ilmiah Kependidikan, 9(2). 1-7.

Soejoto, Ady. (2017). Pelatihan Penulisan Proposal Penelitian Tindakan Kelas (PTK). Jurnal ABDI, 2(2), 51-59.

Supriyanto, Achmad. (2017). Peningkatan Kemampuan Guru Dalam Penulisan Karya Ilmiah Melalui Pelatihan Penelitian Tindakan Kelas. Abdimas Pedagogi, 1(1), 1-7. 